\title{
Overview of the Physical Condition of Football Players of High School Students
}

\author{
Darni*, Ikhbal Elkadiowanda ${ }^{2}$ \\ Sport Education Program \\ Faculty of Sport Education and Health \\ Padang State University \\ Padang, Indonesia \\ darni_po@fik.unp.ac.id ${ }^{1}$
}

\begin{abstract}
The issue of this research is students achievements in playing football, which is caused by their physical condition, including speed, Agility, leg muscle explosive power, and aerobic endurance. The purpose of this research is to recognize students' physical condition in playing football in SMP Laboratorium UNP. This descriptive research involved 20 students who are selected by purposive sampling technique. A 50-meter test collected data of speed, data of Agility were collected by Daging run test, data of le muscle explosive power were collected by standing Board Jump test, and data of aerobic endurance were collected by Bleep test. Descriptive statistics then analyzed the data. Based on the data analysis, the result of this research was (1) student's speed were categorized pair, (2) Student agility were categorized fair, (3) Students' leg muscle explosive power were categorized fair, (4) Students' aerobic endurance were categorized poorly. Therefore, it can be concluded that students' physical condition in playing football in SMP Laboratorium UNP was categorized fairly. Keywords-Physical Condition, Football, Players
\end{abstract}

\section{INTRODUCTION}

The Law of the Republic of Indonesia No. 3 of 2005 on national sport system, stated as follows, "sports achievement is intended as an effort to improve the ability and performance of the sport in order to improve the Harkat and The nation's dignity "[1]. The implementation of football activities in extracurricular activities is one of the students ' coaching efforts, aimed at improving the achievement of football sports in a school. Through extracurricular activities developed a set of materials for the enhancement of football achievements, among others: the formation of physical conditions, techniques, tactics, and mental. In other words, to achieve optimal achievement then the ideal condition or something expected is the formation of a football player that has a good physical condition, master the technique of fine, precise tactics, and a strong mental. From the aspect of physical condition, there are some elements: (1) speed; (2) aerobic power; (3) Leg muscle explosive power; (4) Agility; (5) Leg muscle strength; (6) Balance; (7) Coordination; and (8) flexibility.

The ideal condition or something expected to materialize as above, is different from the reality. Based on the authors ' observation of the Indonesian students ' junior High School Development Laboratory (LPI) in Padang,
2017 looks at some of the following phenomena: first; aspect of speed, there are still many who are less capable of performing counterattacks as quickly as possible to the opponent's defense areas. Their counterattack is often countenable by the speed of the opponent to seize and control the ball. Second Of the aerobic power aspect, still often seen players who are less able to play with fit conditions for $2 \times 35$ minutes. With the meaning of the word, the player can only play well until the second half Paroh. That is, in the last 15 minutes, the player appears to be exhausted so that mistakes are not supposed to happen, for example one anticipates the ball, less accurate in sending the ball towards a friend, and the weakness of concentration. Thirdly, from the aspect of the leg muscle's explosive power, the player often releases a kick that lacks power (less powerful/powered) when giving the bait to a friend, making it easily captured by the opponent. Similarly, when a duel in the air when the opponent kicks a corner, the player often loses to perform a higher jump into the air to seize the ball. Fourth aspect of Agility, still visible players are often late to merobah direction of his position. These often late movements allow opponents to easily seize the ball. Athletes who have good Agility will certainly be able to merobah their body to squeeze, dodge, or make a trick from the opponent's face. Quickly, he can move the position of the body at a specific position as desired and by still being able to control the ball properly.

Based on some of the above phenomena, the findings gained the problem that junior high School of UNP Laboratory development has not demonstrated optimal physical condition, especially in aspects: velocity, aerobic power, limp muscle wartime, and Agility. According to the findings of the above problem, the author is interested to do a study or review about the physical condition of JUNIOR football player of the UNP laboratory development. This important research is held, because without the support of optimal physical condition, certainly good techniques, appropriate tactics, and strong mental will not contribute to each other to Soccer is a game that is done by breaking the ball to be inserted into the opponent's goal and defending its own goal to avoid the entry of the ball. [2] "It can thus be emphasized that the main purpose of playing football is to score as many goals as possible to the opponent's goal, and to avoid or prevent the goal from being conceded. In 
other words, a football team is declared victorious when it can score more goals into the opponent's goal, and vice versa is said to be defeated if scoring fewer goals or not scoring at all. The football team is expressed as strong or a draw if both teams create the same number of goals or not to create a goal at all.

In order to win the victory, a football team must try their hard to score more goals to the opponent's goal. In an effort to gain victory in playing football, a trainer or teacher at a football school needs to prepare physical, technical, tactics, and mental factors as the following image:

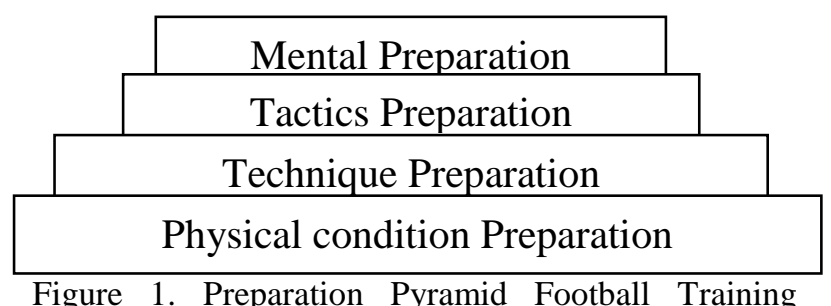

Figure 1. Preparation Pyramid Football Training Program [3]

In accordance with figure 1 above, it is known that the physical condition is the most dominant basic preparation to be able to perform the maximum physical appearance. [3]. In other words, it can be confirmed that to prepare a team of good football, the preparation of the following aspects is required: (1) mental or psychological preparation (psychiatric); (2) Preparation of tactics, tactic or strategy; (3) Preparation of techniques or ways of doing things; and (4) preparation of physical conditions. Of these four elements, the aspect of physical conditions is the most dominant basic preparation that must be prepared in advance in order to perform maximum physical appearance. More strictly speaking, mental preparations, tactics, and techniques will not mean anything, if not supported by good physical condition factors, because:

a. Good physical condition will certainly improve the mental factor (psychological) in the match or play football, for example when doing a penalty kick, mental factors must be supported by good physical condition. To produce a hard or powerful and accurate penalty, it certainly requires physical condition support. A football player will not have strong, high or mental confidence, without the support of optimal physical condition.

b. Good physical condition will be very supportive to run tactics, tactic or strategy wins the game. That is, the tactics or strategy specified in a match or football game will work well, if supported by the optimal physical condition factor.

c. Good physical condition will support the implementation of a soccer technique, for example: fast dribble technique while controlling the ball so that it is not easily taken by the opponent, it cannot be done without the support of the physical condition Optimal. The ability to move rapidly dribble requires a physical condition element of speed. That is, the high technique of playing football can only be achieved, if supported by good physical conditions.

The condition comes from the word conditio (Latin) which means circumstance. Definitively, physical conditions include physical and psychic circumstances as well as the readiness of an athlete against specific demands of a sports branch. This limitation is still too common or too broad because it concerns all aspects of physical (physical) and psychic (spiritual). Therefore, it needs to be limited in physical sense, namely physical condition because the condition in the sense of psychic is the area of research in sports psychology (sport psychology). Physical condition can be interpreted with physical conditions or abilities. According to the intent of the above quotation, it can be explained that physical condition is the condition or physical capability that is the requirement of a sport branch. The physical condition in question, is not included in the psychic aspect because it is a research area of sports psychology (Sport Psychology).

The physical condition terminology means physical state. Such circumstances may include before (initial ability), during and after undergoing the practice process [4]. By summarising some of the above definitions, the physical condition is the physical state or capability required to carry out physical activity on a particular sports branch, either as the initial ability, at the moment, and After experiencing the training process.

\section{Dichotomy Physical condition}

Judging by the difference in the demands on the components of physical condition, physical conditions can be chotomed (differentiated) in general physical conditions and special physical conditions.

\section{a. General physical condition}

d. General physical condition is the basic ability to develop the ability of body achievement consisting of strength, speed, endurance and Kelentukan. A common physical condition exercise means a diverse exercise to develop the body's ability and is the basis for a specific physical condition to be denied. These capabilities include general power, general speed, general durability and general Kelentukan. In reference to the above quote, it can be suggested that a common physical condition is a bodily or physical ability consisting of strength, speed, endurance and Kelentukan. The ability of general physical conditions is the basis for enhancing specific physical conditions. As such, a common physical condition is required for physical (physical) activity in all sports branches [5].

\section{b. Special physical condition}

As stated above, a common physical condition is the basis for the specific physical condition. This means that in order to obtain optimal special physical condition, the exercise of general physical condition is required.In other words, a special physical condition can be interpreted as an ability attributed to the demands or needs of a particular sport. A special physical condition is an optimal exercise of the ability of the condition that 
determines the achievement of a sports branch [7]. In other words that the ability of a special physical condition demonstrates the specificity of a sports branch, because the need for this ability will differ between one branch of sport with another branch or sport. As the intent of the above quotation, it can be explained that a special physical condition is a physical condition that specifically refers to the ability that a person has to achieve achievement in a particular sports branch. When conditions are associated with achievement skills in a particular sport, the conditions herein are referred to as special physical conditions [8].

From the explanation above it can be concluded that the meaning of a special physical condition is the physical condition required by the particular sports branch in order to obtain achievement. In soccer games there are several types of skills that a player has an important thing that is a physical skill consisting of several elements such as: (1) Endurance, (2) Strength, (3) speed, (4) Agility, and (5) Kelentukan. While the skills of mastering the ball consisting of several parts: (1) kicking the ball, (2) receive the ball, (3) dribble (Dribel), (4) Seize the ball, (5) to the ball, (6) motion of guile with Balls, (7) Throwing balls, (8) Techniques of capturing Ball and Pat a special ball for the goalkeeper [3]. Physical conditions are circumstances that include factors of strength, speed, endurance, Kelentukan and coordination. "With the factors that include the physical condition will be seen from the quality of the work performed.

\section{Speed}

The speed of some expert opinion, i.e.:(1) Robinson: Moving speed is the quality that allows people to move, carry out the same or not the same movements as soon as possible; (2) Mathews: Velocity is the conditional ability to produce body movements in the shortest possible time; (3) Kirkendall: Velocity translates to time unity distance; (4) Corbin: Speed is the ability to step from one place to another in the shortest possible time. From the opinion above, it can be concluded that the meaning of speed is the body's ability to direct all its systems to resist the burden, distance and time so as to produce the movement of the body in the shortest possible time [3].

\section{Aerobic Power}

It can be seen from various points of view, such as: duration, intensity, active muscle involvement, and the nature of its work. Nevertheless, the power is generally seen in the point of view of its energy metabolism. If viewed from the energy metabolism angle, then the power is distinguished by two types, namely aerobic endurance (aerobic) and anaerobic power (anaerobic endurance). Durability as follows: Regardless of the side of the view where it is interpreted, generally the power can be interpreted as a person's ability to overcome fatigue due to physical and psychic work for a long time [5]. The sense of the power is more likely to be defined from the physical capability side rather than the psychic (non physical) side. In reference to the above quote, it can be further explained that General Labour is the ability of a person to overcome fatigue due to physical work in a relatively long time. The old size can be in minutes or hours or relative.

Aerobic power is the ability of the heart-lung and vascular system to function optimally when conducting daily activities for a long time without experiencing fatigue that means [7]. Referring to the intent of the above quotation, it can be said that aerobic power is the ability of the heart-lung system and blood vessels to optimally use oxygen so that the body can carry out physical activity in a relatively long time . High aerobic power is needed from an athlete or soccer player. It is said that because the football game is done in a long time (duration), namely: 20 x 20 minutes (under 20 years); 2 x 40 minutes (aged 16-19 years); and $2 \times 45$ minutes (age above 20 years). If there is a strong equal position, it is usually given an extra time, such as $2 \times 15$ minutes [8]. Physical activity in the form of playing football with a relatively long time requires aerobic power to be able to play with a physical condition that is still in shape [9].

\section{Warpower Leg Muscles}

Explosive power of various expert opinions, i.e.:(1) According to Anarino: The explosive power is the strength and speed of muscle contraction dynamically, explosively in rapid time; (2) Corbin: Explosive power is the ability to display/emit power explosively or quickly; (3) Susan: The explosive power depends on the strength of the muscles and the speed of the body [3]. From some of the experts ' opinions mentioned in the above quotations, it seems to be a combination of two abilities, namely strength and speed. Explosive power is the ability to power combinations with a realized speed in the form of muscular ability to cope with the load with a high rate of contraction [6]. Explosive power is an important biomass component in sports activities, since the explosive power will determine how hard people can hit, kick, throw, how fast people run and so on [10]. With this quote it is understandable that explosive power in football among others can determine how hard an athlete or player can kick a ball or run. More strictly speaking, the explosive power in football sports is crucial meaning to kick the ball violently into the opponent's goal, kick the ball on a friend or pass a ball, and run as quickly as possible to the opponent's defensive area while performing an attack Back and forth.

\section{Agility}

Agility is a person's ability to move quickly and change direction with agile. Agility is a combination of speed, strength, reaction speed, balance, flexibility, and neuromuscular coordination [3]. This quotation explains that Agility is not just the ability to move and change direction quickly, but also accompanied by dexterity. Agility in this sense is a combination of some elements of physical condition, namely: speed, strength, reaction speed, balance, flexibility, and coordination. The above quote suggests that Agility is indispensable to sporting activities that require the position speed of the body. Soccer is one of the sports that requires very fast speed, because in football games it takes the speed of the body 
position to change the movement quickly, for example when doing dribbling.

\section{METHODOLOGY}

His research is classified into descriptive research. This research place in SMP Pembangunan Laboratory of UNP Padang. The research population amounted to 59 people. Set as a sample of 20 people with purposive sampling technique. Variable speed measured with a 50-meter run test, aerobic endurance with Bleep Test, a long muscle warhead with a remote jump test, and Agility with Dodging Run Test. In an effort to achieve the objectives and answer questions of this research, then raw data test results of each sub-variable research (speed, aerobic power, leg muscle explosive power, and Agility) will be analyzed using statistics (Frequency tabulation) in the form of frequency calculation (f) and percentage (\%).Formulas or formulations used in the analysis of descriptive statistics in the form of frequency calculation (f) and percentage (\%) is [11]:

$$
\mathrm{P}=\frac{\mathrm{f}}{\mathrm{N}} \times 100
$$

Description:

$\mathrm{P}=$ Percentage $(\%)$ To be searched

$\mathrm{f}=$ Frequency $\quad \mathrm{N}=$ Value or number of respondents

III. RESULTS OF RESEARCH AND DISCUSSION

1. Speed

Table 1. Frequency football player speed distribution

\begin{tabular}{|l|c|c|c|}
\hline \multicolumn{1}{|c|}{ Category } & Speed & Fa & Fr(\%) \\
\hline Very Poor & $>8$ & 2 & 10 \\
\hline Poor & $7.9-6.9$ & 6 & 30 \\
\hline Average & $6.8-5.8$ & 10 & 50 \\
\hline Good & $5.7-4.7$ & 2 & 10 \\
\hline Very Good & $<4.6$ & 0 & 0 \\
\hline \multicolumn{2}{|c|}{ Total } & 20 & 100 \\
\hline
\end{tabular}

Next, based on the category of speed test above, which is 0 people $(0 \%)$ Very good category, 2 people (10\%), good category, 10 people medium category $(50 \%), 6$ people less category $(30 \%)$, while the category is less once 2 people $(10 \%)$. And it can be saved that the speed of junior high school football player UNP Padang Labolatorium belongs to the category of medium.

2. Agility

Tabel 2. Frequency football player Agility distribution

\begin{tabular}{|c|c|c|c|}
\hline Category & Agility & Fa & $\operatorname{Fr}(\%)$ \\
\hline Very Poor & $<16.40$ & 0 & 0 \\
\hline Poor & 14.97-16.39 & 5 & 25 \\
\hline Average & $13.54-14.96$ & 9 & 45 \\
\hline Good & 12.11-13.53 & 6 & 30 \\
\hline Very Good & $>12.10$ & 0 & 0 \\
\hline \multicolumn{2}{|c|}{ Total } & 20 & 100 \\
\hline
\end{tabular}

From the criteria table of agility test above that get a good category 0 people $(0 \%), 5$ people $(25 \%)$ Good category, 9 people (45\%) Medium category, 6 persons $(30 \%)$ In the category of less while the category is less 0 people $(0 \%)$. And it can be concluded that the Agility of junior high school football player Labolatorium UNP belongs to medium category.

\section{Muscular Limbs}

Table 3. Frequency distribution of the player's leg muscles

\begin{tabular}{|c|c|c|c|}
\hline Category & Muscular Limbs & $\mathbf{F a}$ & $\operatorname{Fr}(\%)$ \\
\hline Very Poor & $<113$ & 0 & 0 \\
\hline Poor & 113-149 & 0 & 0 \\
\hline Average & $150-187$ & 13 & 65 \\
\hline Good & $188-224$ & 7 & 35 \\
\hline Very Good & $>224$ & 0 & 0 \\
\hline \multicolumn{2}{|r|}{ Total } & 20 & 100 \\
\hline
\end{tabular}

Based on the table above, it can be attributed to the conclusion that from 20 0rang players who have the position of the muscle legs of the football player Junior High School development laboratory UNP, category both 0 people $(0 \%)$, Category Good 7 people $(35 \%)$, category being 13 people $(65 \%)$ While the category is less 0 people $(0 \%)$, the category is less than 0 people $(0 \%)$. And it can be concluded that the explosive power of the leg muscles of junior high school development of UNP.

\section{Aerobic Endurance}

Table 4. Aerobic Endurance frequency distribution football players Junior high School development of UNP

\begin{tabular}{|c|c|c|c|}
\hline Category & $\begin{array}{c}\text { Aerobic } \\
\text { Endurance }\end{array}$ & $\mathbf{F a}$ & $\operatorname{Fr}(\%)$ \\
\hline Very Poor & $<24$ & 0 & 0 \\
\hline Poor & $25-33$ & 14 & 70 \\
\hline Average & $34-42$ & 6 & 30 \\
\hline Good & $43-52$ & 0 & 0 \\
\hline Very Good & $>53$ & 0 & 0 \\
\hline \multicolumn{2}{|c|}{ Total } & 20 & 100 \\
\hline
\end{tabular}

Based on the table above the aerobic endurance variable from 20 players, the category is high 0 people $(0 \%)$, the category is either 0 people $(0 \%)$, the category is enough 6 people $(30 \%)$, the category is 14 people $(70 \%)$, while the category is low 0 people $(0 \%)$, and it can be concluded that Aerobic Endurance Junior High school football player development of UNP belongs to medium category. 


\section{Physical condition of junior high school football player Development UNP}

Table 5. Frequency distribution of football players physical conditions Junior high School development of UNP

\begin{tabular}{|c|c|c|c|}
\hline Category & $\begin{array}{c}\text { Physical } \\
\text { Condition }\end{array}$ & $\mathbf{F a}$ & $\operatorname{Fr}(\%)$ \\
\hline Very Poor & $<41.94$ & 2 & 10 \\
\hline Poor & 41.94-47.31 & 4 & 20 \\
\hline Average & $47.32-52.69$ & 9 & 45 \\
\hline Good & $52.70-58.06$ & 2 & 10 \\
\hline Very Good & $>58.06$ & 3 & 15 \\
\hline \multicolumn{2}{|c|}{ Total } & 20 & 100 \\
\hline
\end{tabular}

From the table above, it can be concluded that the physical condition of junior high school soccer player UNP development is in medium category.

\section{CONCLUSION}

Based on the results of the study can be expressed the following conclusions: (1) for the speed of the study of junior high school soccer player UNP development is in medium category, (2) aerobic endurance is in the category less, (3) Explosive power Leg muscles are in medium category, (4) agility is in medium category and (5) General physical condition for all above aspects are in medium category.

\section{REFERENCES}

[1] Undang-Undang Republik Indonesia Nomor 3 Tahun 2005 tentang "Sistem Keolahragaan Nasional". Jakarta: Biro Humas dan Hukum Kementerian Negara Pemuda dan Olahraga Republik Indonesia. 2007.pp.20-21

[2] Muhajir. "Pendidikan Jasmani Olahraga dan Kesehatan". Jakarta: Erlangga. 2004.pp.26-27

[3] Arsil. "Pembinaan Kondisi Fisik". Padang: Fakultas Ilmu Keolahragaan Universitas Negeri Padang. 2015.pp77-90

[4] Depdiknas. "Paket Penelitian Kesegaran Jasmani dan Rekreasi di Pusdiklat Olahraga Pelajaran Khusus Sepakbola”. Jakarta: Depdiknas. 2000.pp.11-16

[5] Syafruddin. "Perangkat Pembelajaran Ilmu Melatih Dasar Prestasi Kebugaran Kesehatan". Padang: Fakultas Ilmu Keolahragaan Universitas Negeri Padang. 2017.pp.8-13

[6] Jonath, Ulrich and Rolf Krempel. "Konditionstraining". Hamburg: Rowohlt Taschenbuch Verlag GmbH. 1981.pp.101-112

[7] Wahjoedi. "Landasan Evaluasi Pendidikan Jasmani". Jakarta: PT. Raja Grafindo Persada. 2001.pp.56-67

[8] Yulifri, Y. (2018). Pembinaan Prestasi Sekolah Sepakbola di Kabupaten Padang Pariaman. Jurnal Stamina, 1(1), 451457.

[9] E. Edwarsyah, S. Hardiansyah, and H. Syampurma, "Pengaruh Metode Pelatihan Circuit Training Terhadap Kondisi Fisik Atlet Pencak Silat Unit Kegiatan Olahraga Universitas Negeri Padang," J. PENJAKORA, vol. 4, no. 1, October 2017.

[10] Azham, Arif Qaidul. "Tinjauan Tingkat Kondisi Fisik Pemain Sepakbola SSB Muspan FC Padang". Skripsi. Padang: Fakultas Ilmu Keolahragaan Universitas Negeri Padang. 2015.pp.34-45

[11] Wulandari, Mardiah. Keterampilan Gerak Dasar Anak Taman Kanak-Kanak Pembangunan Laboratorium UNP Padang”. Skripsi. Padang: Fakultas Ilmu Pendidikan Universitas Negeri Padang. 2016.pp.77-88 